\title{
Mot riktigere legemiddelbruk?
}

\author{
Riktig bruk av legemidler er god samfunnsøkonomi, og her har alle leger en jobb å gjøre! Apotekene kan være \\ viktige støttespillere, men da må ikke deres arbeidsbetingelser gjøres for vanskelige.
}

Feilbruk av legemidler er anslått å koste Norge flere milliarder kroner årlig. Stortingsmeldingen «Rett kurs mot riktigere legemiddelbruk» fremsatte riktig legemiddelbruk som det overordnede målet for legemiddelpolitikken. Riktig bruk ble her spesifisert i tre kategorier (1):

1) Legemidler skal brukes riktig - medisinsk og økonomisk

2) Pasienter skal ha sikker tilgang til effektive legemidler, uavhengig av betalingsevne

3) Legemidler skal ha lavest mulig pris

Riktig medisinsk legemiddelbruk medfører færre legemiddelrelaterte problemer, for eksempel unødige sykehusinnleggelser og sykefravær. Økonomisk og medisinsk riktig legemiddelbruk går slik sett hånd $\mathrm{i}$ hånd. Generisk bytte er også en del av riktig økonomisk legemiddelbruk. Generisk bytte kan dessverre medføre feilbruk av legemidler fordi noen pasienter ikke har forstått hva det innebærer. Dersom legen hadde skrevet virkestoff $i$ stedet for handelsnavn på resepten, ville det $\mathrm{i}$ mange tilfeller redusert denne utfordringen.

Apotekets rolle er meget viktig i arbeidet mot riktigere legemiddelbruk. Apoteket er siste mulighet man har for å sikre riktig bruk før pasienten begynner legemiddelbehandlingen. Det er i apoteket at de fleste pasienter blir introdusert for generisk bytte. Disse oppgavene er tidkrevende og apoteket kompenseres ikke direkte for dette arbeidet, men gjennom avansen på salget av legemidlene. $23 \%$ av landets apotek gikk med underskudd i 2009, apotekene er svært presset på tid.

Når Helse- og omsorgsdepartementet gjennom en forskriftsendring fra 1.1.2012 vil kutte prisen på simvastatin med $40 \%$, medfører det en besparelse for folketrygden på 66 millioner kroner og et gjennomsnittlig tap for hvert apotek på 100000 kroner i avanse per år (2). Slike priskutt oppfyller punkt 3 ovenfor, legemidler skal ha lavest mulig pris. Men hva med punkt 1 og 2? Når apotekene mister avansen på legemidler,tvinges de til å selge mer av andre varer, ellers må de stenge. Denne overgangen er særlig vanskelig for distriktsapotekene. Færre apotek i distriktene reduserer pasientenes tilgang til legemidler, punkt 2. Mer salg av andre varer gir mindre tid til ekspedering av legemidler og mindre tid til å sikre riktig bruk av legemidler, punkt 1 .

Helse- og omsorgsdepartementet bør nyttegjøre samfunnets store innsparingspotensial i å minske feilbruk av legemidler. Apoteket kan være arenaen for dette, men da må noe skje før landets apotek er blitt til sminkeutsalg, som i England.

\section{Georg Beiske}

Avdeling for helseledelse og helseøkonomi og

Farmasøytisk Institutt

Universitetet i Oslo

Georg Anton Giæver Beiske (f. 1989) er farmasistudent og bachelorstudent i helseledelse og økonomi ved Universitetet i Oslo. Ingen opplyste interessekonflikter.

\section{Litteratur \\ 1. St.meld. nr. 18 (2004-2005). Rett kurs mot rikti- gere legemiddelbruk. \\ 2. Nilsen $L$. HOD vil tvinge frem lavere statinpris. Dagens Medisin 1.9.2011.}

Mottatt 18.9.2011 og godkjent 20.10.2011. Medisinsk redaktør Anne Kveim Lie.

\section{SOP og pensjonsløgnen}

I 35 år har jeg arbeidet som heltids allmennlege. Fra 1974 til 1993 har jeg hatt redusert normaltariff grunnet innbetaling til SOP. Fra 1972 til 2003 er jeg i alle Legeforeningens årbøker blitt lovet alderspensjon lik overlege i staten. Dette løftet ble brutt, tilbakevirkende, i 2005.

Min kone, sykehuslege siden 1972, døde i 2006. Legeforeningen/SOP bruker nå den tragedien at min kone er død til å spare penger. De samordner min alderspensjon mot min etterlattepensjon i KLP. 35 år som allmennlege, 39 år som medlem av Legeforeningen er pensjonsmessig nullet ut.

Jeg ønsker ikke å være medlem i en for- ening med dette lavmål av etikk og moral. Jeg har meldt meg ut av Legeforeningen.

\section{Harald Hauge Drøsdal \\ hdrosdal@online.no \\ Nesbru}

Harald Hauge Drøsdal (f. 1944) er pensjonert lege.

Ingen oppgitte interessekonflikter.

Mottatt 9.10. 2011 og godkjent 3.11. 2011. Medisinsk redaktør Erlend Hem. 